\title{
Tumefação cervical direita
}

\author{
Right neck swelling
}

Figura 1. Abcesso cervical de actinomicose.

Os autores apresentam o caso de um homem de 54 anos de idade, com antecedentes de diabetes mellitus tipo 2 e cáries dentárias múltiplas em tratamento. Tratava-se de um doente com história de abcessos cervicais recorrentes com 6 anos de evolução, sem etiologia identificada, com necessidade de antibioterapia e intervenções cirúrgicas múltiplas.

Recorreu ao serviço de urgência por tumefação cervical direita, dolorosa, com 2 semanas de evolução. Negava outra sintomatologia. Ao exame objetivo a destacar: tumefação cervical direita com sinais inflamatórios exuberantes, áreas de flutuação à palpação e celulite dos tecidos circundantes (Figura 1). Analiticamente apresentava leucocitose ligeira e elevação da proteína $C$ reactiva.

Realizou ecografia cervical que revelou colecção heterogénea compatível com abcesso e celulite adjacente, confirmada por tomografia computorizada (TC) cervical (Figura 2). 0 exame histológico do material purulento revelou lamelas de queratina e colónias bacterianas. 0 estudo microbiológico isolou Actinomyces spp. Admitiu-se o diagnóstico de actinomicose cervicofacial, tendo iniciado penicilina endovenosa em dose elevada. Apresentou evolução clínica favorável, com reavaliação imagiológica a evidenciar involução da lesão.

A actinomicose é uma infecção bacteriana crónica rara, causada por um grupo de bactérias Gram-positivo, anaeróbias, que colonizam a cavidade oral e tractos gastrointestinal e genital. A forma cervicofacial é a mais frequente, constituindo 50 a $65 \%$ dos casos $^{1,2}$.

A explanação deste caso clínico, pretende enfatizar a importância da suspeição diagnóstica desta entidade perante o doente com história de abcessos cutâneos recidivantes associados a insucesso terapêutico. Salienta-se ainda a importância da antibioterapia dirigida e prolongada.

\section{Bibliografia}

1. Russo TA. Agents of actinomycosis. In: Mandell GL, Bennett JE, Dolin R, eds. Mandell, Douglas and Bennett's principles and practice of infectious diseases. $7^{\text {th }}$ ed. Philadelphia, Pa: Churchill Livingstone Elsevier, 2010; 3209-3219.

2. Wong VK, Turmezei TD, Weston VC. Actinomycosis. BMJ. 2011; 343:d6099.

\section{Diagnóstico: Actinomicose}

\section{Paula Paiva, Alexandre Louro}

Serviço de Medicina Interna. Unidade Local de Saúde do Norte Alentejano. Portalegre. Portugal

Correspondencia: pmdpaiva@hotmail.com

Como citar este artículo: Paiva P, Louro $\mathrm{A}$

Tumefação cervical direita. Galicia Clin 2016; 77 (3): 146

Recibido: 17/02/16; Aceptado: 03/03/16

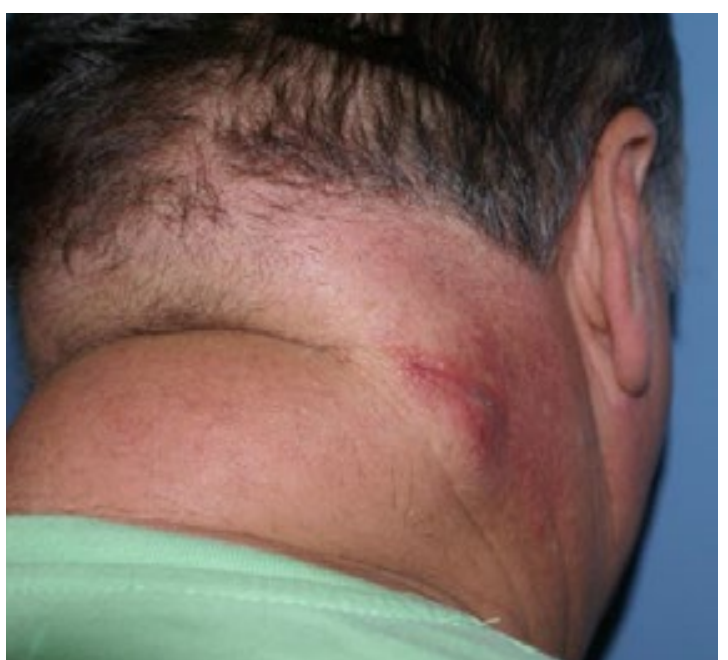

Figura 2. TC cervical: A - corte axial; B - corte sagital; abcesso localizado aos planos profundos da gordura subcutânea na vertente posterior direita do pescoço $(42 \times 24 \times 34 \mathrm{~mm})$. Alterações inflamatórias da gordura adjacente com espessamento cutâneo difuso.

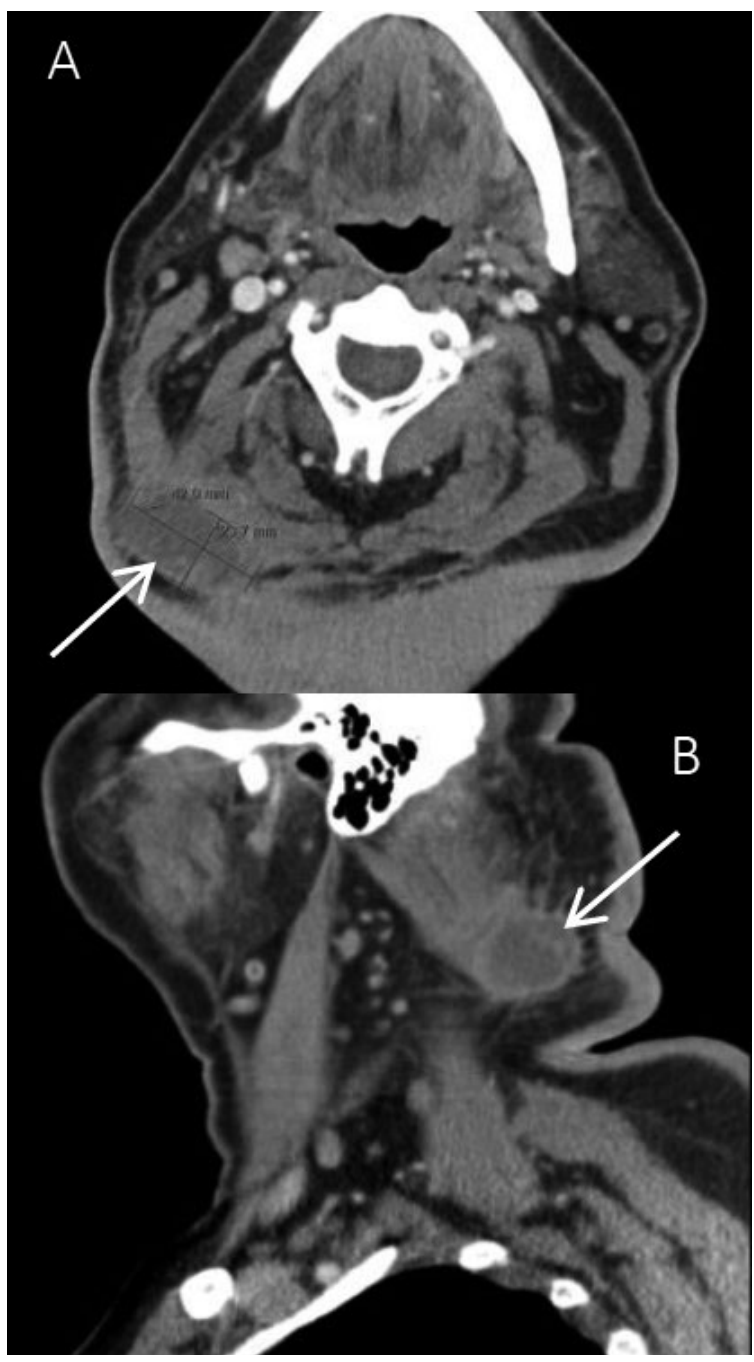

